\title{
6. The global growth of higher education philanthropy and fundraising
}

Noah D. Drezner

Individuals and cultures are generous around the world. Yet, formal philanthropy given by individuals manifests differently in diverse contexts, with various practices and traditions impacting giving (Bekkers, 2016). Plewes (2008) notes that although formal philanthropy is often thought of as a phenomenon of the Global North, recently there has been growth in formal philanthropic activity in the Global South. The Charities Aid Foundation's World Giving Index (2017) found that nearly one-third ( 30 per cent) of the world's population donates money to others.

Individuals around the world give to various different causes (Wiepking \& Handy, 2016a). Support of secular and religious causes differ across country contexts, economic and political factors and their relation to the welfare state (Abbasov \& Drezner, 2018; Bekkers, 2016; Einolf, 2017; Wiepking \& Handy, 2016b). Individual donors in most countries support social services, youth, health, religion and natural disaster relief (Wiepking \& Handy, 2016a). However, higher education is often not supported, or is supported to a much lesser extent, by individual donors as it is still viewed as the responsibility of the government (Johnstone, Arora \& Experton, 1998; Wiepking \& Handy, 2016a).

While many educational institutions around the world were founded with the generosity of church leaders, royalty, industrial philanthropists and other donors, systematic and organised philanthropic giving and fundraising towards higher education, up until relatively recently, was solely a U.S. phenomenon. However, there has been significant growth around the world in the number of countries that are encouraging such support of institutions. One measure of the growth of fundraising for higher education is the number of countries that are represented in the main professional association for practitioners of educational fundraising. Currently there are 61 countries that have individual colleges and 
universities as members of the Council for the Advancement and Support of Education (CASE), a U.S.-based association (Figure 6.1).

These changes to higher education philanthropy raise many questions. Chief among them is what are the possible explanations for the growth of fundraising and philanthropy globally? In this chapter, I am going to posit three possible explanations: first, that there is a functional need for philanthropic support of higher education; second, that this trend is a form of isomorphism where institutions are striving for prestige; and, third, the growth of philanthropy can be explained as a function of borrowing and lending of perceived best practices. It is important to note that none of these explanations are 'pure'. They are complex, with aspects overlapping and interactions with politics, policies and other phenomena.

\section{THE FUNCTIONAL ARGUMENT: THE GROWING NEED FOR PHILANTHROPIC DOLLARS}

Perhaps the simplest explanation for the expansion of fundraising for higher education is the need for an additional revenue source. Johnstone (2005) noted that 'throughout the world, governments are increasingly accepting the premise that tax revenues alone are insufficient to sustain public institutions of higher education in the face of increasing costs and, in most countries, increasing participation and enrolments' (p. 256). He argues that there are steeply rising costs to higher education that are outpacing the ability of government to meet with tax revenue alone. ${ }^{1}$ Johnstone (2005) argues that the lack of government support results in 'increasing institutional austerity manifested by overcrowding, deterioration of physical plants, demoralization and outright loss of faculty, and limitations on capacity-and thus on higher educational opportunities' (p.257). As such, he contends that most OECD countries have placed philanthropy as a revenue source on their agenda of university financial reforms. Philanthropy is an 'enormously attractive political solution precisely because it is not taxes and it is not tuition fees' (Johnstone, 2005, p. 257).

Using the United States as a case, it is fairly easy to show that the need for budget relief is a possible driving force. Within the landscape of public higher education in the United States, there has been a shift of the burden

1 UNESCO argues that the lack of tax revenue is complex. In their Education for All Global Monitoring Report 2013/14 they caution that some developing countries might be able to increase spending on education through increased spending efficiency and the closing of tax loopholes that favour transnational corporations. 


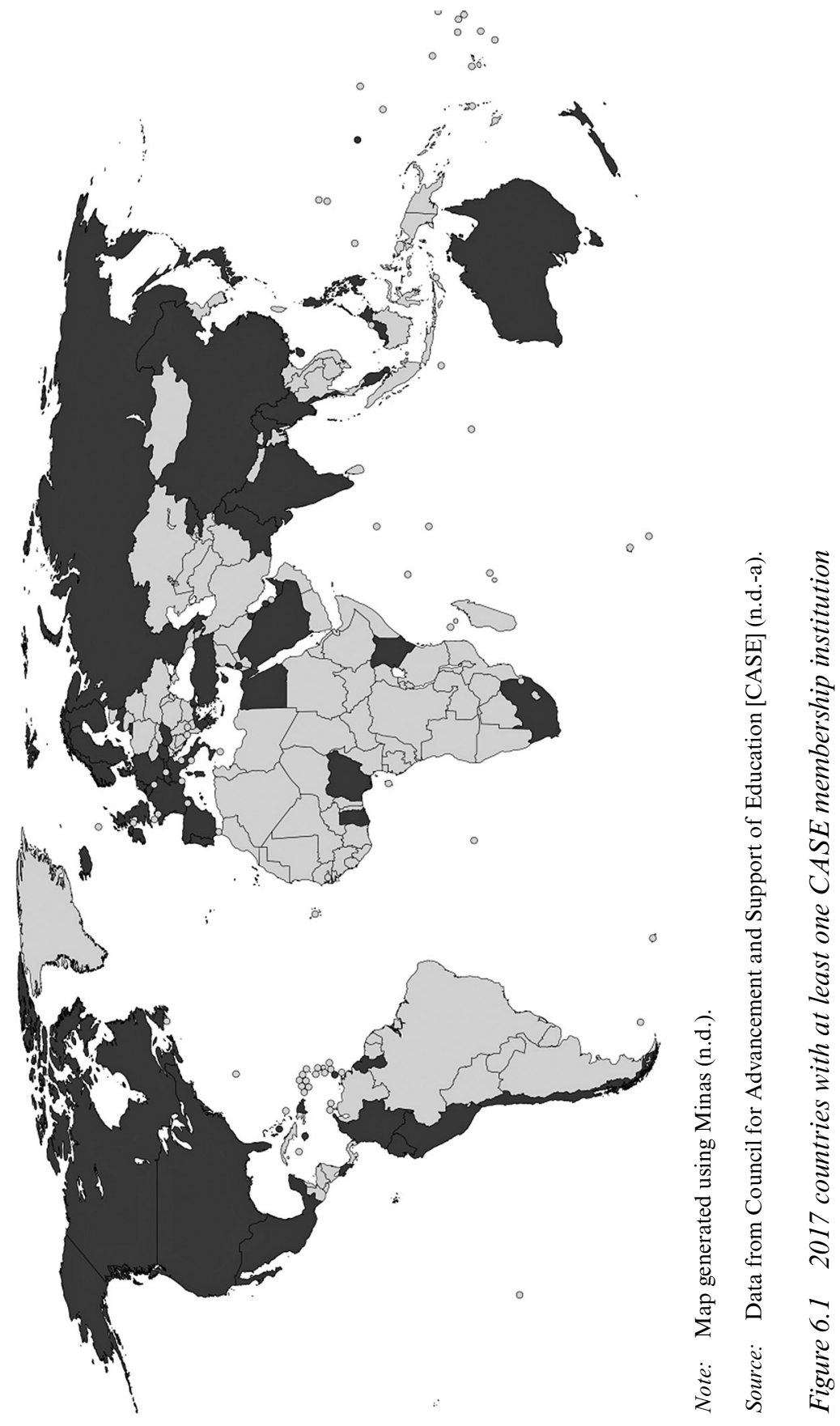




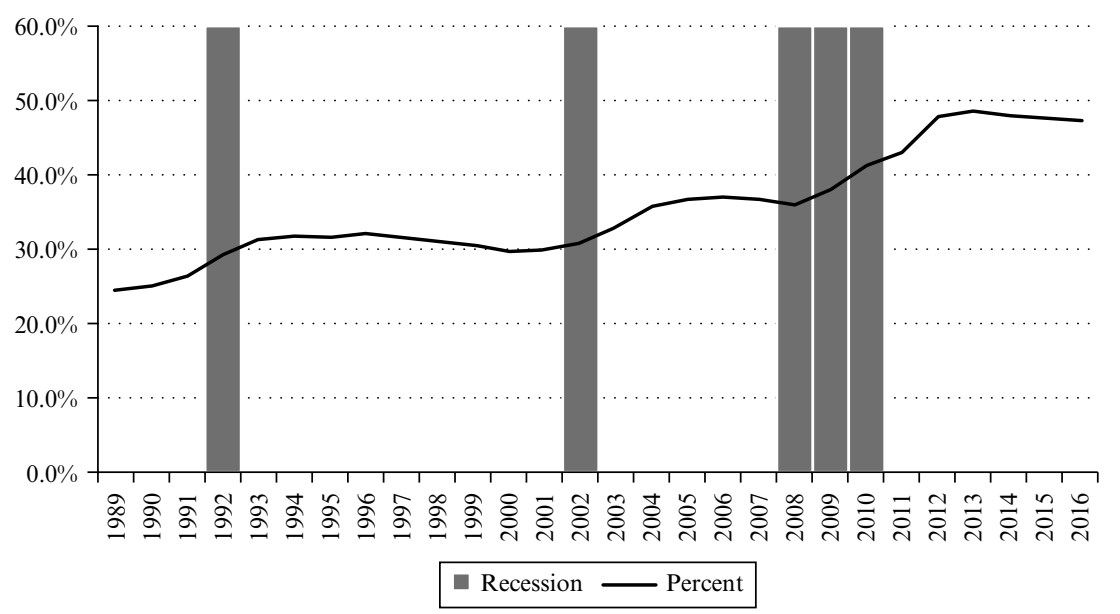

Source: Data from State Higher Education Executive Officers Association $(2014,2016)$.

Figure 6.2 Net tuition as a per cent of public higher education revenue, 1989-2016

of who is responsible for higher education. This shift is part of a larger move of higher education being seen more as a private good than a public good (Davies, 2015; Drezner, 2018; Grier \& Bownes, 2014; Leat, 2016). Up until the 1970s, philanthropic support of U.S. higher education was virtually restricted to the private colleges and universities (Drezner, 2011; Johnstone et al., 1998). However, as public revenue support began to wane, state institutions began to move to philanthropy.

Net tuition revenue in U.S. public higher education has grown most rapidly as a percentage of total educational revenue in public institutions over at least the past few decades. The increase in dependence on tuition as a portion of revenue has increased more rapidly during periods when state support per student has declined, such as during economic downturns (Figure 6.2). The funding situation for public higher education has only worsened since the 2001-2002 recessions. In the wake of that recession, the percentage of state institutional budgets that came from student tuition and fees surpassed the portion that came from government appropriations (Moody's, 2011) (see Figure 6.3). With government support decreasing and the cost of education increasing, tuition has been rising across higher education. As such, in order to reduce the financial burden on students, public and private institutions began to focus more attention on other forms of institutional revenue, such as philanthropy. Philanthropic giving was viewed as having the potential to both lower the reliance on tuition 


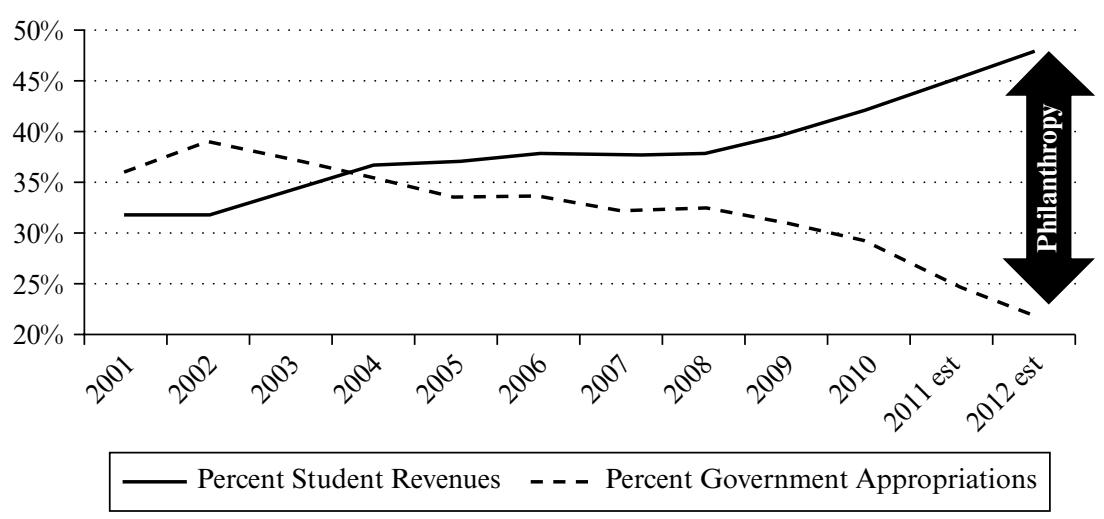

Source: Adapted from 'Weekly Credit Outlook, 43' 31 October 2011. Copyright 2011 by Moody's. https://www.moodys.com/researchdocumentcontentpage.aspx?docid=PBC_136951.

Figure 6.3 Public university funding burden shift to students

to make budget and provide needed scholarships that discount the tuition and increase college access.

This functional need for philanthropy is not only in the United States. Over the last four decades, access to Chinese higher education has tremendously expanded, with nearly half (42.7 per cent) of traditionally aged college students seeking a college degree (Ministry of Education of the People's Republic of China, 2017). While nearly all Chinese colleges and universities are publicly funded by the Central and provincial governments, per student funding has not kept up with the growth of enrolment (Ministry of Education of the People's Republic of China, 2015, 2017). Furthermore, although per student funding has fallen, institutions are feeling pressure to fulfil the national educational strategy to strive for worldclass status. Salmi (2011) argues that Chinese institutions, in part, need additional funding to meet budget shortfalls and enable institutions to make decisions in order to achieve their goal of world-class status. As such, many institutions within China are turning towards philanthropic giving. According to the China Foundation Center (2018), currently, nearly onefifth (19 per cent) of all, or 495, Chinese higher education institutions have established foundations for fundraising purposes. However, when looking at world-class status institutions, ${ }^{2}$ all have opened foundations.

2 On 24 October 2015, China's State Council officially announced an initiative to create and support China's world-class university ambition. The initiative includes central and local 


\section{THE ISOMORPHIC ARGUMENT: STRIVING FOR PRESTIGE AND LEGITIMACY}

In their seminal study, DiMaggio and Powell (1983) argue that isomorphism, or homogeneity of structure, can take multiple forms. This includes competitive isomorphism that can arise from economic pressures and institutional isomorphism stemming from organisational constraints. DiMaggio and Powell further described three mechanisms of institutional isomorphism: (1) coercion, where pressure from other organisations, including the state, pushes homogeneity; (2) mimicking, in which imitation is brought on by uncertainty within a field; and (3) the creation of norms that are often imposed by professions. As a result of institutional isomorphism, 'as an innovation spreads, a threshold is reached beyond which adaptation provides legitimacy rather than improves performance' (DiMaggio \& Powell, 1983, p. 148).

Scholars have explored globalisation and isomorphism within the context of governance and organisational models of philanthropic foundations (Harrow, 2011; Rey-Garcia \& Puig-Raposo, 2013). However, beyond governance, the decision to actively fundraise and to successfully attain large sums of philanthropy for higher education can be viewed through the lens of isomorphism. The economic pressures described as part of competitive isomorphism were discussed in my functional argument. However, institutional isomorphism explains other aspects of the global growth of higher education fundraising.

For example, the isomorphic principles of seeking prestige and legitimacy over needs and performance can be seen through the lens of rankings both in the United States and worldwide. In the United States, there are both explicit and implicit ways that philanthropy is used in rankings as a means to measure prestige and legitimacy. The U.S. News \& World Report rankings methodology, in 2018, used alumni giving as an explicit measure of satisfaction and post-graduate engagement (this measure accounted for five per cent of the total score/ranking). Alumni giving is operationalised in the form of percentage of participation, or in other words, the average percentage of living alumni with bachelor's degrees who donated over the past two years. However, there are also implicit measures of philanthropy including financial resources (accounting for 10 per cent of the total

governments' financial support and concentrated resources on selected universities. The goal of the world-class university initiative is three-fold: by 2020, a number of Chinese universities and subject areas will be recognised as having achieved world-class standing; by 2030, more universities and subject areas will have world-class status, with some universities at the top of the global rankings; and by 2050, China will have the leading universities and fields of study across the world (Zha, 2016). 
score/ranking), which include endowment per full-time equivalent student. Additionally, there is a measure of academic reputation by academic leaders (accounting for 22.5 per cent of the total score/ranking). Academic reputation can be impacted by alumni giving, capital campaign success, publicity and the like. U.S. News \& World Report admits that while 'endowment size isn't a direct factor in the rankings. . . declines could affect other rankings factors' (Morse, 2013, p. 1). In total, three out of the six, or half, of the measures that inform the U.S. News \& World Report rankings could be affected by philanthropy.

In global rankings, as of now, there is no explicit measure of philanthropy. However, there is implicit use of philanthropy, like in the U.S. News \& World Report rankings. For example, The Times Higher Education world rankings measure academic reputation (accounting for 33 per cent of the total score/ranking). In many ways, while philanthropy is not an explicit part of rankings, it is taken for granted that the ability to raise and attract philanthropy is an indicator of quality. Through the engagement with rankings, striving institutions will act on alumni giving and other forms of philanthropy.

Further, there is a level of mimicking, as DiMaggio and Powell (1983) note, among institutions of higher education striving for elite status. Colleges and universities who are continually noted as the most elite institutions are the same ones that are most successful with philanthropy. This holds true in the United States and the United Kingdom. For example, in the United States, three-quarters of the USD 500 billion in endowment wealth is currently held by just 11 per cent of colleges and universities (Sherlock, Gravelle, Crandall-Hollick \& Stupak, 2015), all of which are highly ranked by U.S. News \& World Report. Additionally, more than 25 per cent of the USD 41 billion raised by colleges in 2016 went to just 20 U.S. institutions (Kaplan, 2017). Similarly, in the United Kingdom, nearly four-fifths (78 per cent) of new philanthropic gifts were secured in 2014-2015 by only 18 institutions (Ross-CASE, 2016). In the following year, 2015-2016, 16 institutions raised nearly all of the money secured (97 per cent), accounting for $£ 266.7$ million or USD 373.5 million (Ross-CASE, 2017).

We can begin to see the impact of isomorphism within the Asian context. Although universities in Hong Kong, Singapore and China are well-funded by their governments, the governments have noted that university research departments are driving forces in the international comparisons and global rankings. Therefore, endowment funding for research and scholarships has become more important (Sharma, 2011). The governments of Singapore and Hong Kong have encouraged giving by promising matching government funding. In Singapore's case, the 
match is more than 1.5 times the donated figure. The Hong Kong Secretary General for Continuing Education in Tertiary Institutions was quoted as saying, 'People do not give to poor universities, they give to excellent universities' (Sharma, 2011, p. 1). This quote is evidence that the seeking of philanthropy, at least in part, is about striving for prestige.

\section{THE BORROWING \& LENDING ARGUMENT: ADOPTION OF 'BEST PRACTICES'}

Steiner-Khamsi (2004) defines the normative endeavour of borrowing and lending as understanding 'what can be learned and imported from elsewhere (borrowing), as well as what can be taught and exported to elsewhere (lending)' (pp. 1-2). Within the context of higher education, philanthropy and fundraising borrowing and lending is mostly occurring in the form of institutions and countries adopting 'best practices' mostly from the United States, but also from the United Kingdom and other Western countries. This can be seen through documentation in Chinese academic journals (e.g., U.S. practices: Chen \& Feng, 2011; Chen \& Tan, 2007; Lin \& Hong, 2010; Ya, 2012; Yan \& Hong, 2011; Zou \& Lv, 2010; U.K. practices: Hong \& Hu, 2012; Liang \& Hong, 2017, 2018; Yang \& Wang, 2017; Canadian practices: Dekun, 2010; and Australian practices: Leiyu \& Hong, 2011). Interestingly, there is not a lot of evidence of mimicking fundraising practices from other parts of Asia, such as Hong Kong or Singapore.

One such form of borrowing and lending can be seen through the proliferation of CASE member institutions. CASE is the leading practitioner organisation for educational fundraising. As I noted earlier, there has been exponential growth in CASE's global footprint in recent years, with 61 countries having at least one member institution. There are 503 member institutions outside the United States and Canada and CASE offices in Washington, DC, London (opened in 1994), Singapore (opened in 2007), and Mexico City (opened in 2011).

William Squire (2014) chronicles the adoption of U.S. higher education fundraising practices in the United Kingdom. He noted 'the growing U.K. interest in U.S. practice was paralleled by a similar interest from the U.S. side in promoting fundraising in support of British higher education' (p. 32). The CASE involvement in the United Kingdom began with a Fulbright U.S./U.K. Administrative Exchange Program in the 1980s, where senior development directors from U.S. institutions spent a year at top British institutions. Squire (2014) describes these exchanges as a "process of "technology transfer" whereby successful techniques for fundraising in US higher education were adapted and applied to UK 
conditions' (p.33). Throughout the 1990s, the Partnership became more formalised with U.K.-based CASE conferences and the establishment of a CASE office in London.

Since 2004, the CASE Board of Trustees and the CASE Europe Board of Trustees have adopted four statements affirming CASE's principles for internationalisation. Within these documents, you can see CASE's commitment to the principles of borrowing and lending. However, like with many borrowing and lending processes, it seems to be asymmetrical. For example, in the 2007 'Oxford Accord', CASE agreed upon 10 principles, of which four touch on borrowing and lending:

- CASE will pursue its growth and development as both an international organization (one that incorporates international perspectives into its overall operations) and as a global organization (one that provides services appropriate to various regions around the world).

- In entering new markets, CASE may consider any initial investment as an act of 'enlightened philanthropy', recognising that all members benefit from the increased understanding and professionalism of educational advancement around the world.

- CASE's success in serving new markets will depend heavily on understanding local needs and engaging local practitioners by helping them to adapt (and not simply adopt) best practices from well-established programs.

- In its professional development programs, CASE will respect both cultural differences and core principles related to educational advancement. (CASE, 2007)

These principles, perhaps because of CASE being a practitioner association, seem to focus on them lending best practices, mostly from the United States to other parts of the world. Language such as 'provides services appropriate to various regions around the world,' that their work is 'enlightened philanthropy' or that they want 'new markets. . . to adapt (not simply adopt) best practices', are all examples of an asymmetrical relationship when it comes to fundraising practice.

Beyond the borrowing of best practices, CASE has received over USD 2 million in grants from the Carnegie Corporation of New York to create infrastructures at institutions around the world for alumni giving and philanthropy. Over half of those grants were directed towards 'build[ing] advancement programs in parts of Africa... by offer[ing] training in fundraising and alumni relations to university leaders and advancement professionals' (CASE, n.d.-b). The consultants tasked with this work are often U.S.-based and some are from the United Kingdom. 
Similarly, other foundations are invested in African university capacity building without CASE. These grants were made through the Partnership for Higher Education in Africa. This Partnership was a consortium of seven major U.S. foundations including Carnegie Corporation of New York and the Ford, William and Flora Hewlett, Kresge, John D. and Catherine MacArthur, Andrew W. Mellon, and Rockefeller Foundations. While all of these foundations invested in building university capacity including fundraising, The Kresge Foundation focused on building the infrastructure, including the data systems necessary for strong advancement programmes in South African universities (Jaumont, 2016).

While the intent of CASE and the U.S. foundations was to help institutions of higher education advance, by exporting U.S. ideas around philanthropy and fundraising, these organisations might have inadvertently disregarded cultural differences. It is encouraging that CASE, in its 'Oxford Accord' affirmed the organisation's commitment to 'respect both cultural differences and core principles'. However, when ideas are borrowed and lent to others rather than them being developed within a cultural context concerns about applicability arise.

\section{LARGER QUESTIONS AND CONCERNS WITH THE GLOBAL GROWTH OF HIGHER EDUCATION PHILANTHROPY BY INDIVIDUALS}

Regardless of what might explain the global growth of the higher education philanthropy, larger questions and concerns arise. As noted above, there are different cultures of philanthropy across countries and regions (Bekkers, 2016; Einolf, 2017; Wiepking \& Handy, 2016b). My own work, within the U.S. context, has shown that there are different cultures of and motivations for philanthropy towards higher education across social identity groups (Drezner, 2005, 2009, 2013, 2017, 2018; Drezner \& Garvey, 2016). As such, fundraising practices that work for one group do not necessarily work for other potential donors. Given these differences, what works in practice in the U.S. and the U.K. will not work everywhere. Therefore, colleges and universities that might want to develop cultures of giving among alumni and other supporters must not simply borrow from the U.S. and other more mature fundraising institutions; they should adapt and translate practices to work within their own contexts.

Beyond the different cultures of and motivations for giving, there are different socio-logics or understandings of the purpose of higher education within different national contexts. This might impact how individuals understand the need or feel the responsibility to give towards the education 
of other citizens. There is a lack of research on individual giving towards higher education outside of the U.S. context. Scholars should engage questions such as, what does fundraising for higher education mean within a neoliberal context versus a welfare state context? Or, within a comparative paradigm, how does individual education philanthropy look in different socio-logics? In other words, how does it look in individualist societies, such as the United States, or collectivist societies, like China?

\section{Future Directions for Research}

There are a number of directions for future research that would help us better understand the global growth of higher education philanthropy. For example, the global growth in fundraising should be measured in different ways than the proliferation of CASE institutional memberships. In order to do so, researchers could look at which institutions are engaged in fundraising. This would include not only an examination of those that have joined CASE but a look at what structures and levels of engagement institutions have in place.

Further research should explore the emergence of cultures of giving towards higher education in different contexts. Comparative research on donor motivations is important. For example, are donors motivated in different countries to give educational philanthropy in similar ways? How does tax policy and incentives motivate donors? Do extrinsic and intrinsic motivations for giving operate similarly in different cultures?

Beyond research that engages questions of donor motivation, to better understand this global growth of philanthropy, researchers should not just focus on the action of the donor. Scholars should research the professionalisation of the field of academic fundraising. Prior to now, most researchers have focused on the individual donor, their characteristics and their motivations; however, to best understand the growth of fundraising, it is important to flip the script and theorise, through empirical research, our understanding of the professionalisation of this field in comparative contexts (see Breeze, 2017).

\section{CONCLUSION}

Over the past few decades, institutions of higher education and governments around the world have been seeking out individual donors and putting polices in place that would encourage giving. On the surface, one might believe that this increased interest in philanthropic support of higher education might just be due to a need to balance budgets. However, this 
functional reason is only one possible explanation for this potentially more complex phenomenon. For example, the growing obsession with rankings and striving for prestige and legitimacy in higher education (O'Meara, 2007) points to isomorphism being a possible explanation for more institutions seeking out philanthropic support, regardless of there being a need for or a culture of philanthropic support of education within their country. Additionally, with the continued professionalisation of the field of higher education fundraising, the branching out of CASE beyond North America and the investment of U.S. foundations in building fundraising infrastructures abroad, principles of policy and practice borrowing and lending emerge as a final explanation.

As many institutions and governments look to U.S. success at fundraising and the subsequent ability to depend on endowment returns, it is important to reflect on the undergirding fundamentals that support these philanthropic gains. Large-scale philanthropy obviously requires a substantial concentration of wealth. However, it also needs favourable tax incentives for philanthropic giving and a culture of voluntary support for colleges and universities (Drezner, 2011; Johnstone, 2005; Johnstone \& Marcucci, 2010). Building these traditions of giving are not easy or immediate, especially in countries and socio-logics in which the population being asked to give have historically viewed higher education as the financial responsibility of the state.

\section{REFERENCES}

Abbasov, A., \& Drezner, N. D. (2018). Exploring educational philanthropy in Azerbaijan: Charitable giving behaviors among the university alumni. Journal of International and Comparative Higher Education, 10(1), 2-12.

Bekkers, R. (2016). Regional differences in philanthropy. In T. Jung, S. D. Phillips, \& J. Harrow (Eds.), Routledge companion to philanthropy (pp. 124-138). New York, NY: Routledge.

Breeze, B. (2017). The new fundraisers: Who organises charitable giving in contemporary society? Bristol, UK: Policy Press.

Charities Aid Foundation. (2017). CAF World Giving Index 2017: A global view of giving trends. West Malling, UK: Author.

Chen, C. W., \& Tan, J. (2007). On the relationship of the tax policy and the philanthropy: The experience of the United States and its Enlightenment. Journal of Social Science of Hunan Normal University, 6, 016.

Chen, X., \& Feng, Q. (2011). On the donations and donor behaviors of Chinese higher education. Peking University Education Review, 1, 010.

China Foundation Center. (2018). Foundation Database. Retrieved March 1, 2018, from http://en.foundationcenter.org.cn/online.html

Council for Advancement and Support of Education. (2007). The Oxford Accord. Washington, DC: Author. Retrieved October 27, 2017, from https://www. 
case.org/About_CASE/Volunteer_Leadership/Board_of_Trustees/The_Oxford_ Accord.html

Council for Advancement and Support of Education. (n.d.-a). The CASE institutional member directory. Retrieved November 5, 2017, from https://store.case. org/PersonifyEbusiness/Default.aspx?TabID $=472$

Council for Advancement and Support of Education. (n.d.-b). International initiatives. Washington, DC: Author. Retrieved November 5, 2017, from https://www. case.org/About_CASE/International_Initiatives.html

Davies, R. (2015). Public good by private means: How philanthropy shapes Britain. London, UK: Alliance Publishing Trust.

Dekun, W. (2010). Inspiration of Canadian university social financing practice. China Higher Education, 60(6), 61-62.

DiMaggio, P., \& Powell, W. W. (1983). The iron cage revisited: Collective rationality and institutional isomorphism in organizational fields. American Sociological Review, 48(2), 147-160.

Drezner, N. D. (2005). Advancing Gallaudet: Alumni support for the nation's university for the Deaf and hard-of-hearing and its similarities to Black colleges and universities. International Journal of Educational Advancement, 5(4), 301-315.

Drezner, N. D. (2009). Why give?: Exploring social exchange and organizational identification theories in the promotion of philanthropic behaviors of African American millennials at private-HBCUs. International Journal of Educational Advancement, 9(3), 147-165.

Drezner, N. D. (2011). Philanthropy and fundraising in American higher education (ASHE Higher Education Reports). San Francisco, CA: Jossey-Bass.

Drezner, N. D. (Ed.). (2013). Expanding the donor base in higher education: Engaging non-traditional donors. New York, NY: Routledge.

Drezner, N. D. (2017). Philanthropy and social identity: Taking the concept of philanthropic mirroring and placing it in the Bulgarian context to enhance higher education fundraising practice. In P. Boyadjieva \& R. Stoyanova (Eds.), The gift and cultures of giving for education: Theories, institutions, individuals (pp. 75-94). Sofia, Bulgaria: Iztok-Zapad.

Drezner, N. D. (2018). Philanthropic mirroring: Exploring identity-based fundraising in higher education. Journal of Higher Education, 89(3), 261-293. https://doi. org/10.1080/00221546.2017.1368818

Drezner, N. D., \& Garvey, J. C. (2016). LGBTQ alumni philanthropy: Exploring (un)conscious motivations for giving related to identity and experiences. Nonprofit and Voluntary Sector Quarterly, 45(IS), 52s-71s.

Einolf, C. J. (2017). Cross-national differences in charitable giving in the west and the world. VOLUNTAS: International Journal of Voluntary and Nonprofit Organizations, 28(2), 472-491.

Grier, J., \& Bownes, M. (2014). Private giving, public good: The impact of philanthropy at the University of Edinburgh. Edinburgh, UK: Edinburgh University Press.

Harrow, J. (2011). Governance and isomorphism in local philanthropy: The interplay of issues among foundations in Japan and the UK. Public Management Review, 13(1), 1-20.

Hong, C., \& Hu, Y. (2012). Financing strategies and implications of Cardiff University in the United Kingdom. International and Comparative Education [China], (7), 25-29. 
Jaumont, F. (2016). Unequal partners: American foundations and higher education development in Africa. New York, NY: Palgrave Macmillan.

Johnstone, D. B. (2005). A political culture of giving and the philanthropic support of public higher education in international perspective. International Journal of Educational Advancement, 5(3), 256-264.

Johnstone, D. B. \& Marcucci, P. N. (2010). Financing higher education worldwide: Who pays? Who should pay? Baltimore, MD: JHU Press.

Johnstone, D. B., Arora, A., \& Experton, W. (1998). The financing and management of higher education: A status report on worldwide reforms. Washington, DC: World Bank.

Kaplan, A. (2017). Voluntary support of education. New York, NY: Council for Aid to Education.

Leat, D. (2016). Philanthropic foundations, public good and public policy. London, UK: Palgrave Macmillan.

Leiyu, M., \& Hong, C. (2011). Research on financing strategies of Queensland University of Technology. Journal of National Academy of Education Administration [China], (2), 85-90.

Liang, X., \& Hong, C. (2017). UK higher education matching fund policy: Development, effect and enlightenment. International and Comparative Education [China], 39(4), 69-75.

Liang, X., \& Hong, C. (2018). Social funding of higher education in Western developed countries: Experience, characteristics and trends. International and Comparative Education [China], 40(3), 98-105.

Lin, T. L., \& Hong, C. W. (2010). Research on the new development ideal of American public universities and the effective fundraising strategies - taking Indiana University as example. Comparative Education Review [China], 5, 014.

Minas. (n.d.). Mapchart.net [Website]. Retrieved October 27, 2017, from https:// mapchart.net/

Ministry of Education of the People's Republic of China. (2015). 2014 National education development statistics bulletin. Beijing, China. Retrieved March 1, 2018, from http://www.moe.edu.cn/jyb_xwfb/gzdt_gzdt/s5987/201507/t20150730_196 698.html

Ministry of Education of the People's Republic of China. (2017). 2016 National education development statistics bulletin. Beijing, China. Retrieved March 1, 2018, from http://www.moe.edu.cn/jyb_sjzl/sjzl_fztjgb/201707/t20170710_309042.html

Moody's. (2011). Weekly Credit Outlook, 31 October, 43. Retrieved October 5, 2016, https://www.moodys.com/researchdocumentcontentpage.aspx?docid=PBC 136951

Morse, R. (2013). Decline in endowments may affect best colleges rankings. U.S. News \& World Report. Retrieved October 27, 2017, from https://www.usnews.com/ education/blogs/college-rankings-blog/2013/02/07/decline-in-endowments-may-af fect-best-colleges-rankings

O'Meara, K. (2007). Striving for what? Exploring the pursuit of prestige. In J. Smart (Ed.), Higher education: Handbook of theory and research (pp. 121-179). Dordrecht, Netherlands: Springer.

Plewes, B. (2008). Global philanthropy and international cooperation: A guide to trends and issues. Vanier, ON: Canadian Council for International Co-operation.

Rey-Garcia, M., \& Puig-Raposo, N. (2013). Globalisation and the organisation of family philanthropy: A case of isomorphism?. Business History, 55(6), 1019-1046.

Ross-CASE (2016). Giving to excellence: Generating philanthropic support for UK 
higher education. London, UK: Council for the Advancement and Support of Education.

Ross-CASE (2017). Giving to excellence: Generating philanthropic support for UK higher education. London, UK: Council for the Advancement and Support of Education.

Salmi, J. (2011). The road to academic excellence: Lessons of experience. In P. G. Altbach \& J. Salmi (Eds.), The road to academic excellence: The making of worldclass research universities (pp. 323-347). Washington, DC: The World Bank.

Sharma, Y. (2011, April 24). ASIA: The rise of higher education philanthropy. University World News, 168. Retrieved October 27, 2017, from http://www. universityworldnews.com/article.php?story $=20110421201619136$

Sherlock, M. F., Gravelle, J. G., Crandall-Hollick, M. L., \& Stupak, J. M. (2015). College and university endowments: Overview and tax policy options. (Congressional Research Service Report). Washington, DC: Congressional Research Service.

Squire, W. (2014). University fundraising in Britain: A transatlantic partnership. Leicestershire, UK: Troubador Publishing.

State Higher Education Executive Officers Association. (2014). State Higher Education Finance (SHEF): FY 2014. Boulder, CO: Author. Retrieved October 25, 2017, from http://www.sheeo.org/sites/default/files/project-files/SHEF\%20 FY\%202014-20150410.pdf

State Higher Education Executive Officers Association. (2016). State Higher Education Finance (SHEF): FY 2016. Boulder, CO: Author. Retrieved October 25, 2017, from http://www.sheeo.org/sites/default/files/project-files/SHEEO_ SHEF_2016_Report.pdf

Steiner-Khamsi, G. (Ed.). (2004). The global politics of educational borrowing and lending. New York, NY: Teachers College Press.

UNESCO. (2014). Teaching and learning: Achieving quality for all (EFA Global Monitoring Report 2013/14). Paris, France: Author. Retrieved March 5, 2018, from http://unesdoc.unesco.org/images/0022/002256/225660e.pdf

Wiepking, P., \& Handy, F. (Eds.). (2016a). The Palgrave handbook of global philanthropy. New York, NY: Springer.

Wiepking, P., \& Handy, F. (2016b). Explanations for cross-national differences in philanthropy. In P. Wiepking \& F. Handy (Eds.), The Palgrave handbook of global philanthropy (pp.9-21). London, UK: Palgrave Macmillan.

Ya, D.E.N.G. (2012). The importance of the operation mechanism for alumni affairs in promoting universities' fundraising capabilities: An international and comparative perspective. Peking University Education Review, 1, 015.

Yan, L., \& Hong, C. W. (2011). The fundraising strategy of MIT and its inspiration. Journal of Higher Education [China], 4, 022.

Yang, W., \& Wang, D. (2017). Implications of the British government's Thomas Report to the management of China's education fund. Tsinghua Journal of Education, 38(4), 87-93.

Zha, Q. (2016). China calls for smarter standards for its world-class universities. International Higher Education, (86), 10-11. https://doi.org/10.6017/ihe.2016.86. 9363

Zou, X. D., \& Lv, X. F. (2010). Alumni complex: the main cause of American higher education donation. Comparative Education Review [China], 7, 014. 